Vol. 4, $n^{\circ} 2 \mid 2000$

Varia

\title{
Counting crimes or counting people : some implications of mid-nineteenth century British police returns
}

Chris A. Williams

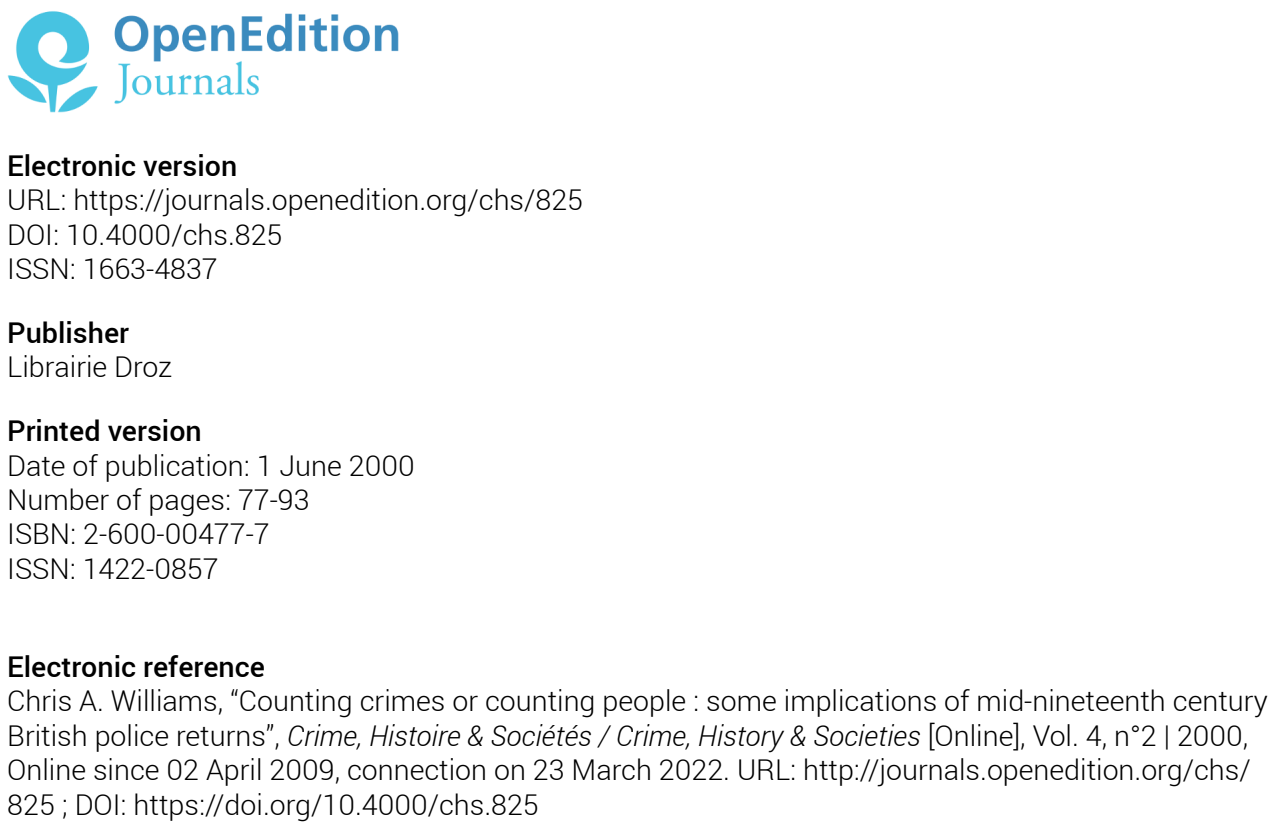




\title{
Counting crimes or counting people: some implications of mid-nineteenth century British police returns ${ }^{1}$
}

\author{
Chris A. Williams ${ }^{2}$
}

\begin{abstract}
Police returns for the city of Sheffield, 1844-1862, underpin the case that the arrest is a better base for analysis than the 'crime'. The number of convictions for indictable offences is less than $5 \%$ of the total of arrests, which are dominated by offences related to disorder rather than to property, violence, or regulation. Age profiles of those convicted on indictment are different from those arrested. Treatment through the criminal justice process - itself capable of constructing some measurements by retrospective labelling - differed markedly by gender, which was also differentially affected by the extension of summary jurisdiction in the 1840s and 1850s. Modelling the cumulative impact of arrests leads to the conclusion that by the 1860s, a surprisingly large number of men would have had experience of arrest.
\end{abstract}

Les statistiques de police de la ville de Sheffield pour la période 1844 1862 montrent que, pour l'analyse, l'arrestation est un meilleur indicateur que l'infraction. Le nombre de condamnations pour des délits représente moins de $5 \%$ du total des arrestations, où dominent les infractions relatives à l'ordre public, plutôt qu'aux biens, à la violence ou aux règlements. Le profil des âges des condamnés diffère de celui des interpellés. L'intervention de la justice pénale - qui reconstruit certains indicateurs par le biais de catégorisations rétrospectives - varie beaucoup suivant le sexe, variable également affectée de façon spécifique par l'extension de la procédure simplifiée de jugement dans les années 1840-1850. En modélisant l'impact cumulé des arrestations on est amené à conclure que dans les années 1860, un nombre étonnamment important d'hommes auront fait l'expérience de l'arrestation.

A re we still hypnotised by the legacy of attempts to gauge the « dark figure » A of crime? This article attempts to re-direct analysis of available crime statistics away from measurement of «crime» through serious (in the British context, indictable) offences, towards a greater focus on the activity of the criminal justice

1 This article is derived from my doctorate on 'Police and Crime in Sheffield, 1818-1874', researched in the History Department of the University of Sheffield under the supervision of David Martin and John Woodward. It was further developed courtesy of the Economic and Social History Department at Leicester University. A number of useful comments on it were also received from Clive Emsley, Pete King and Lucy Faire, and the exceptionally careful and conscientious attention of one of this journal's referees was most welcome. The remaining errors are mine.

2 Dr. Chris Williams is a research fellow at the European Centre for the Study of Policing (Open University, UK). He has published: Expediency, authority and duplicity: reforming Sheffield's police 1832-1840, in Trainor R. and Morris R. (Eds), Urban Governance : Britain and Beyond Since 1750, Ashgate, Aldershot, 2000. His current research deals with Police violence and policing violence since 1945 . 
system and its impact. The first part looks at the underlying assumptions behind three different positions in the debate on British historical criminal statistics. Through examination of Sheffield's police returns, part two identifies the «arrest» rather than the «crime» as the more secure foundation for speculation on the activity of the criminal justice system, and shows the extent to which the profile of those convicted on indictment differed from that of those arrested. Part three assesses an attempt to model the cumulative numerical impact of arrests, while part four uses progression through the courts to illustrate the extent to which offenders were «labelled» and to gauge the gendered impact of legislative changes in the 1850s.

I.

Three different approaches to the historical study of criminal statistics can be identified. They can be labelled as «positivist», «interactive» and «pessimist». The first holds that the criminal statistics can tell us something about the state of crime; the second, that they are most informative about the activity of the criminal justice system ; and the third, that none of their content can be trusted, thus their only use is as a guide to the image of crime. The «positivist» view is that criminal statistics can give us some information - however distorted - about variations in the pattern of crime. Its most quoted exponents have been Gatrell and Hadden, who argued that the pattern of nineteenth-century crime can be linked to economic fluctuations, and that the main impact of the "new police» was to reduce crime by successfully tackling the activity of a criminal class ${ }^{3}$. D.J.V. Jones used the records of Wales's courts to deliver a picture of « real crime» in the principality ${ }^{4}$. The «interactionist » view is that quantitative data can tell us about crime but only through the medium of changes in the criminal justice system: it thus is better for giving a picture of the interaction between state institutions and social forces. Philips concluded that: «Offences cannot be treated as simple entities on their own, but must be considered in the context of their reciprocal relationship with the law and law enforcement $»^{5}$.

Tobias and Sindall have been most robust in defence of the «pessimist» position $^{6}$. Howard Taylor has recently given more ammunition to this view, with his work proposing the hypothesis that the prosecution rates for certain crimes were driven entirely by financial considerations that were external to the functioning of the criminal justice system itself ${ }^{7}$. Taylor's view, though, continues the pattern of attacking the weak points (in this case, homicide) rather than the strong ones. His work on British police policy in the inter-war years of the twentieth century shows how one statistical indicator - crimes known to the police - was indeed consciously manipulated. Yet this indicator does not comprise all «the statistics $»^{8}$.

\footnotetext{
3 Gatrell and Hadden (1972); Gatrell (1980).

4 Jones (1992, pp. 240-251). This approach is not entirely, or even mainly, confined to British historians: Chassaigne (1993); Garnham (1997).

$5 \quad$ Philips (1977, pp. 41-43).

Tobias (1967); Sindall (1990).

Taylor H. (1998a).

Taylor H. (1998b, p. 25).
} 
This article will place itself firmly in the «interactionist» group, and hold that some forms of nineteenth-century criminal statistics can be used to follow the activity of the criminal justice system. It will attempt to replace the «crime» with the «arrest» as the starting point that forms the basic unit of any quantification. This requires a re-definition of the theoretical position that has sometimes been taken towards criminal statistics. «The statistics» are not a unity, to be accepted or rejected as a whole. Some measurements - such as the post- 1857 returns of criminals at large, or the nineteenth-century police returns for indictable convictions - are deeply flawed. Others - such as numbers of private warrants for assault - can serve as accurate indicators of the activity of some forms of the criminal justice system. A «pessimist» style of analysis, seeing the numbers as entirely constructed, useful only as an input to attitudes, certainly has its place for many numerical sources, some of which can indeed only be seen in this light.

It is possible to identify two different paradigms in the conceptualisation of crime. One view sees crime as mainly indictable, and therefore best represented by «serious» crimes of property. Philips's work on the Black Country falls into this category ${ }^{9}$. The other looks at the activity of the criminal justice system as a whole, concluding that interaction is dominated by «petty» crime. Gatrell and Davis, fall into this second category, seeing petty crime as the key determinant of police-public interaction ${ }^{10}$. Their studies are mainly qualitative: this is intended to add another quantitative dimension, and extend it back to before 1856. Newspaper court reports of this period sometimes contain phrases such as: "There were several cases of disorderlies [sic] not worthy of very particular mention ${ }^{11}$. Yet it is important to both mention and try to make sense of the cumulative mass of petty offences because this constituted the major type of encounter between police and public. Davis's research has shown the central place that the dispensing of summary justice at Petty Sessions occupied in working-class urban life in the second half of the nineteenth century ${ }^{12}$. Thus the mass of minor charges is interesting from the point of view of the community at large: how was the police's intervention chiefly felt?

Most commentators have seen «the statistics» as being synonymous with the Home Office statistical returns ${ }^{13}$. Other forms exist - notably those detailing all the activity of various municipal forces ${ }^{14}$. This article will consider some uses to which one particular set of returns - those of the Sheffield City police between 1845 and 1862 - can be examined.

9 Philips (1977, p. 84).

10 Gatrell (1990, pp. 279-281); Davis (1984, p. 312).

11 Sheffield Independent, April 19, 1845. Also see the Birmingham Journal: «On Monday there were forty prisoners, and on Tuesday forty-two brought before the magistrates charged with trifling offences not worth reporting», September $18,1841$.

12 Davis (1984); Davis (1989); Gatrell (1990, p. 251).

13 Tobias in fact provides an interesting exception to this trend, given that he critically examined the returns for Leeds. Tobias (1967, pp. 296-308).

14 For an examination of Manchester's returns, see Jones (1982). For Hull see Welsh (1997); Birmingham's government-run police force $(1840-1842)$ printed weekly details of all the criminals it brought before the magistrates in the local newspapers. Birmingham Journal, 1840. 
II.

This article will concentrate on the Sheffield police returns for mid-century. Sheffield was one of the largest cities (although officially it remained a «town" until 1893) in England, with a population of 135,000 in 1851, growing at a rate of around $25 \%$ every ten years. Economically, it occupied a key niche in the world's production of steel and other metal products. The handicraft grinding sector, generally organised in small workshops, was being joined by an expanding heavy specialist steel casting sector. In each, there was a significant degree of economic mobility for some members of the working class, either through advancement to employer status, or through increasing experience to a highly-skilled job. Sheffield was exceptional in some ways, but its thriving tertiary sector was very similar to that of other large towns, and it was big enough to be, in itself, a significant component of the English urban scene.

Its criminal justice system was similar to that of most boroughs. There was a strict division between indictable offences, which covered most property crime and the more serious crimes of violence, and which could only be tried at the West Riding Quarter Sessions (six per year), or twice-yearly Yorkshire Assizes. Otherwise, criminals were tried summarily by local magistrates at daily Petty Sessions in Sheffield. From 1847 juveniles, and from 1855 adult offenders, could be tried summarily for some minor indictable crimes if they pleaded guilty. The system was characterised by stages and decisions : the policeman's decision to arrest; the charge in court; the initial verdict of the magistrates. Those charged with indictable offences were committed to future trial, and faced a further (largely symbolic) sifting by the Grand Jury, before their eventual conviction or acquittal.

The Criminal and Miscellaneous Statistical Returns of the Sheffield Police Force recorded these processes in action ${ }^{15}$. They were presented annually by the Chief Constable to the Watch Committee, who then printed and distributed two hundred copies ${ }^{16}$. The composition of the distribution list, and the monthly breakdowns in the returns, make it very unlikely that the figures were subject to largescale manipulation. For the years 1844-55 inclusive, they consisted of a set of tables for each year, giving the number of people dealt with divided up by gender and offence. They record the numbers who each month were arrested; those discharged by the magistrates ; those convicted summarily; those committed for trial for indictable offences; and the outcome of this trial. Other tables show ages of those arrested, and age, sex and sentence of those convicted on indictment. In 1856 and 1857 the returns were re-organised and contain little compatible information: from 1858 to 1862 they reverted to the earlier format, but gave more information on age. The period of analysis here is driven by availability constraints rather than any theoretical basis. The Returns provide the source for all otherwise unattributed numerical material in this article.

Table One shows the outcomes for all offences for the years 1844-1855. Each line is a subset of the first: the final three lines are additionally a subset of the number committed for trial on indictment.

15 Criminal and Miscellaneous Statistical Returns of the Sheffield Police Force, Sheffield Local Studies Library.

16 Sheffield Town Council Watch Committee Minutes (hereafter, «WCM»), April 18, 1848. The recipients included all the magistrates, all the town councillors, and local libraries. 
Table One: Outcomes for those arrested, 1844-1855.

\begin{tabular}{|l|c|c|c|c|c|c|}
\hline & Male & Female & Total & Male \% & Female \% & Total \% \\
\hline Arrested & 34229 & 5671 & 39900 & 100.0 & 100.0 & 100.0 \\
\hline $\begin{array}{l}\text { Discharged } \\
\text { by the Magistrates }\end{array}$ & 8819 & 2935 & 11754 & 25.8 & 51.8 & 29.5 \\
\hline $\begin{array}{l}\text { Summarily convicted, } \\
\text { or held to bail }\end{array}$ & 23272 & 2369 & 25641 & 68.0 & 41.8 & 64.3 \\
\hline $\begin{array}{l}\text { Convicted under } \\
\text { Criminal Justice Act }\end{array}$ & 89 & 37 & 126 & 0.3 & 0.7 & 0.3 \\
\hline $\begin{array}{l}\text { Convicted under Juvenile } \\
\text { Offenders' Acts }\end{array}$ & 134 & 26 & 160 & 0.4 & 0.5 & 0.4 \\
\hline $\begin{array}{l}\text { Committed for trial } \\
\text { on indictment }\end{array}$ & 1915 & 304 & 2219 & 5.6 & 5.4 & 5.6 \\
\hline $\begin{array}{l}\text { Convicted and sentenced } \\
\text { on indictment }\end{array}$ & 1550 & 241 & 1791 & 4.5 & 4.2 & 4.5 \\
\hline Acquitted on indictment & 317 & 49 & 366 & 0.9 & 0.9 & 0.9 \\
\hline $\begin{array}{l}\text { 'Bill not found' by Grand } \\
\text { Jury, or not prosecuted }\end{array}$ & 48 & 14 & 62 & 0.1 & 0.2 & 0.2 \\
\hline
\end{tabular}

Summary prosecutions involved far more people than indictable ones: only around one in twenty of those arrested (an even smaller proportion of those proceeded against) were convicted of an indictable offence. Gatrell has pointed to the fact that, in the mid to late nineteenth century, there was a tendency for those convicted of larceny to have been arrested multiple times ${ }^{17}$. This $5 \%$ figure could therefore refer to an even smaller number of individuals.

It is useful to look at the figures for «indictable offences known to the police», which are included in the Home Office return series from 1857, mainly in a "pessimistic» sense: i.e. purely as a potential indicator of public concern and determined more, than anything else, by changes in police policy: between forces or over time. As M. Young and $\mathrm{H}$. Taylor have demonstrated, this measure is deeply unreliable, and open to manipulation by the police authorities ${ }^{18}$. To use it uncritically, for instance as Smith has in his analysis of the social structure of several large English towns in the mid-nineteenth century, is to base conclusions on very shaky foundations ${ }^{19}$.

Arrests are used here as the basic measure of the data. An arrest - compulsorily depriving the individual of his or her physical freedom - is a significant exercise of

17 Gatrell (1980, p. 326).

18 Young (1991, p. 323). Taylor shows how one of the best manipulators of this measure, Leonard Dunning, referred to it as a «discretionary statistic». Taylor H. (1998b, p. 12).

19 Smith (1982, p. 57). 
the state's power over the individual, and we can be reasonably sure that the returns present an accurate image of the numbers of arrests and the fates of those arrested. It is possible to draw some immediate conclusions from the numbers of arrests over the whole period. The figure of 39900 arrests between 1844 and 1856 equates to an annual average of 3325 .

Reduced to a rate per 100000 , the arrest rate was as given in Table Two below. The rate per policeman alters in the period after 1858 . The most likely explanation for this break is a change of policiy stemming from the top: a new Chief Constable took over in 1858 .

Table Two: Arrests and police work-rate.

\begin{tabular}{|c|c|c|c|c|c|c|c|c|}
\hline Year & $\begin{array}{c}\text { Number } \\
\text { arrested }\end{array}$ & Population $^{20}$ & $\begin{array}{c}\text { Number } \\
\text { of police }\end{array}$ & $\begin{array}{c}\text { Number } \\
\text { arrested } \\
\text { per } \\
100,000\end{array}$ & $\begin{array}{c}\text { Number } \\
\text { arrested per } \\
\text { policeman }\end{array}$ & \multicolumn{3}{|c|}{$\begin{array}{c}\text { Method of trial possible } \\
\text { for each offence }\end{array}$} \\
\hline & & & & & & Indictable & Both & Summary \\
\hline 1845 & 2556 & 120201 & 109 & 2,126 & 26.36 & 357 & 344 & 1854 \\
1846 & 2873 & 122593 & 109 & 2344 & 24.59 & 324 & 388 & 2161 \\
1847 & 2680 & 125033 & 109 & 2143 & 24.59 & 392 & 424 & 1864 \\
1848 & 3006 & 127521 & 109 & 2357 & 27.58 & 440 & 370 & 2196 \\
1849 & 3093 & 130059 & 109 & 2378 & 28.38 & 429 & 491 & 2173 \\
1850 & 3187 & 132647 & 109 & 2403 & 29.24 & 342 & 537 & 2308 \\
1851 & 3806 & 135287 & 119 & 2813 & 31.98 & 329 & 578 & 2899 \\
1852 & 4149 & 139591 & 119 & 2972 & 34.87 & 405 & 554 & 3190 \\
1853 & 3864 & 144044 & 119 & 2683 & 32.47 & 424 & 643 & 2797 \\
1854 & 4014 & 148639 & 119 & 2701 & 33.73 & 491 & 744 & 2779 \\
1855 & 3377 & 153380 & 119 & 2202 & 28.38 & 551 & 531 & 2295 \\
1856 & 3295 & 158273 & 134 & 2082 & 24.59 & 572 & 614 & 2106 \\
1857 & -23 & 163322 & 176 & - & - & - & - & - \\
1858 & - & 168532 & 176 & - & - & - & - & - \\
1859 & 3128 & 173908 & 191 & 1799 & 16.38 & - & - & - \\
1860 & 2787 & 179456 & 191 & 1553 & 14.59 & - & - & - \\
1861 & 3065 & 185180 & 191 & 1655 & 16.05 & - & - & - \\
1862 & 2784 & 190042 & 216 & 1465 & 12.89 & - & - & - \\
\hline
\end{tabular}

20 The population estimate is calculated on the basis of a constant percentage growth over the period in between Censuses. The data also refers to the whole borough, not just the "watched and lighted" area: the police jurisdiction extended over the borough as a whole, and they arrested people within the entire area, even if they did not comprehensively patrol it.

21 This total is the complement of the police force: it was not necessarily kept up to this complement, and thus it should be seen as a maximum figure, and probably an overestimate by up to around $10 \%$.

22 This table excludes four arrests for crimes that only ever led to discharges: three counts of «coining" and one of «assault with intent to commit an unnatural crime».

23 For 1857 and 1858 , the only figures provided are for those subject to conviction: they include those proceeded against by summons, and thus are not compatible with the arrests series. From 1859 , the definition of «indictable» and summary has been changed by legislation. 
The vast majority of the arrests were for offences that could only be tried summarily. In 9 out of 12 years, as well, arrests for crimes that could be tried in either fashion outnumbered those that could only be tried on indictment. For crimes that could be tried either way - a category dominated in the returns by common assault - the vast majority were tried summarily. So, of 3,655 men arrested for assault in the period 1844-1855, just 13 were tried on indictment. Of the 39,900 arrests, 22,835 were for «disorder» offences, chiefly related to drunkenness, 6,214 for property crime, 5,938 for miscellaneous offences, and 4,913 for crimes of violence ${ }^{24}$. The returns show that many more different people were proceeded against for assault, disorderliness, or a variety of regulatory offences, than for indictable offences. In strictly numerical terms, summary justice was substantially more important. This has an important bearing on the debate about the nature and timing of the process whereby the new police became the «default» public prosecutor in the English courts ${ }^{25}$. If most summary prosecutions concerned offences of «disorder», when there was generally no identifiable victim, then the police had to handle a large number of summary cases themselves, from the very start of their institutional existence. The development of the police as the sole prosecutors, therefore, was not a departure from their former role, but an extension of it.

An arrest is one discrete and countable starting point that occurs in a large proportion of criminal cases. For «disorder» rather than for a specific reported "crime», there is no objective sequence that runs (with ever smaller totals) 'reported crime $\rightarrow$ arrest $\rightarrow$ prosecution $\rightarrow$ conviction' from which we can extract or extrapolate «real crime» ${ }^{26}$. Instead, the sequence for many arrests runs «arrest $\rightarrow$ prosecution $\rightarrow$ conviction». «Disorderly» offences do not feature a crime that is reported and recorded as such. Instead, a police officer makes a decision initially to label an event as a crime (or, more accurately, a person as a criminal) and then proceeds to make an arrest. The initial survey of the types of offence dealt with, therefore, reinforces the conclusion that, as measured by arrests, summary petty crime is a highly important constituent part of the criminal justice system, and this cannot be measured in the same way as indictable crime.

One further illustration of this point can be seen in the population's age data. Comparable information exists on the ages of the prisoners available for two different categories over the period 1844-1856. The first is for those arrested $(39,900)$. The second is for the 1791 of those who were tried and convicted for indictable offences. These two profiles of ages are different: further evidence that the offender profiles for indictable offences cannot be used as a proxy for «all crime».

24 Here, «disorderly » is defined narrowly in order to underline the conclusion that it is a key element. Several offences that might contain a regulatory motive, such as «disorderly apprentices ", "gambling», and «breach of the peace», are here included as «miscellaneous». The full breakdown is available in Williams (1998, pp. 305-308).

25 See for instance, Hay and Snyder (1989, p. 37).

26 D. Taylor repeats this model in his overview of the Nineteenth Century: Taylor D. (1998, p. 15). 


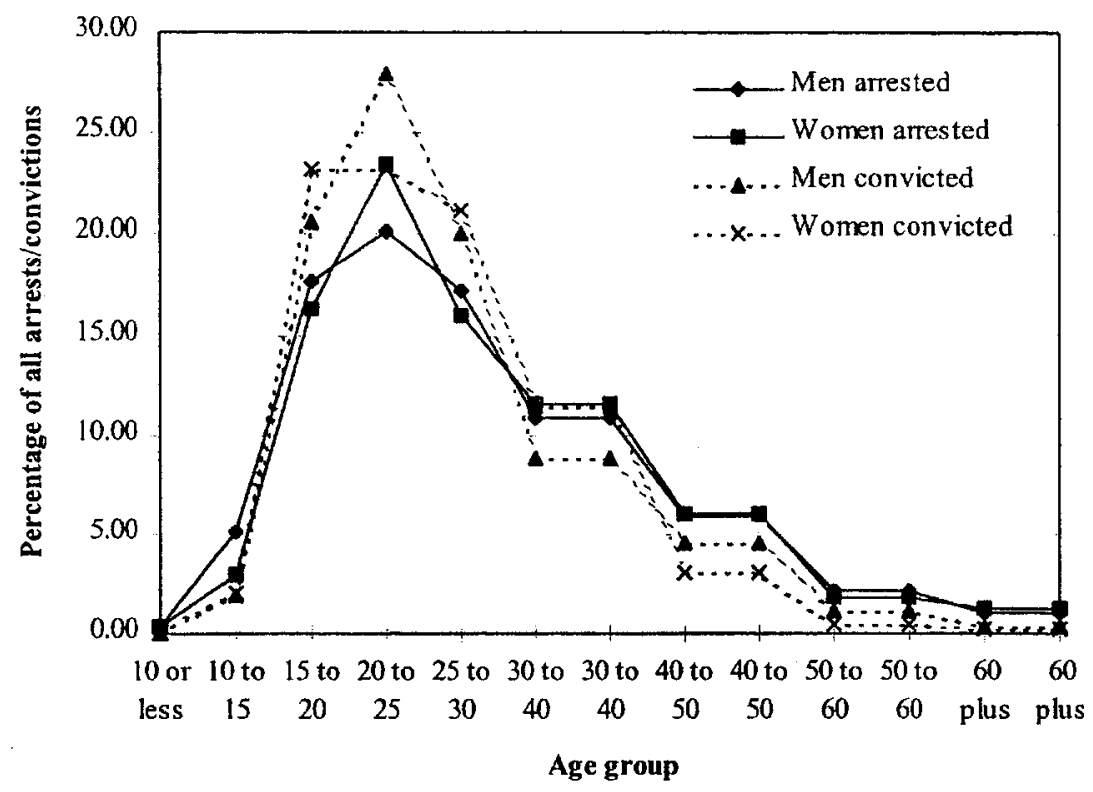

Graph One: Age profiles of arrests and indictable convictions, 1845-5.

Graph One shows the age profiles of those arrested and of those convicted for indictable offences respectively. The ages are not aggregated evenly - they are grouped in 5-year cohorts between 10 and 15, and 10-year cohorts outside these ages. The cohorts over 30 have been halved (therefore « 30 to 40 » and older age ranges appear twice on the $\mathrm{x}$-axis) to preserve as much detail as possible whilst giving an accurate impression of the age profile. Over the period just 101 boys and 18 girls were arrested: none were sentenced on indictment, although this was theoretically possible. Despite mid-Victorian concern with juvenile crime, the number of 10 to 15 year olds arrested is remarkably small ${ }^{27}$. Even the next age group up, 15 to 20 , accounts for only about 7,000 of the arrests, while between them, the next two five-year cohorts account for 8,200 and 6,800 arrests.

27 They bear interesting comparison with those for the Old Bailey in the 1790 s and 1820 s presented by King and Noel. The Sheffield figures appear to show that prosecuted crime was becoming less «juvenile», although for several reasons they are not directly comparable. King and Noel (1993, pp. 26-27). 


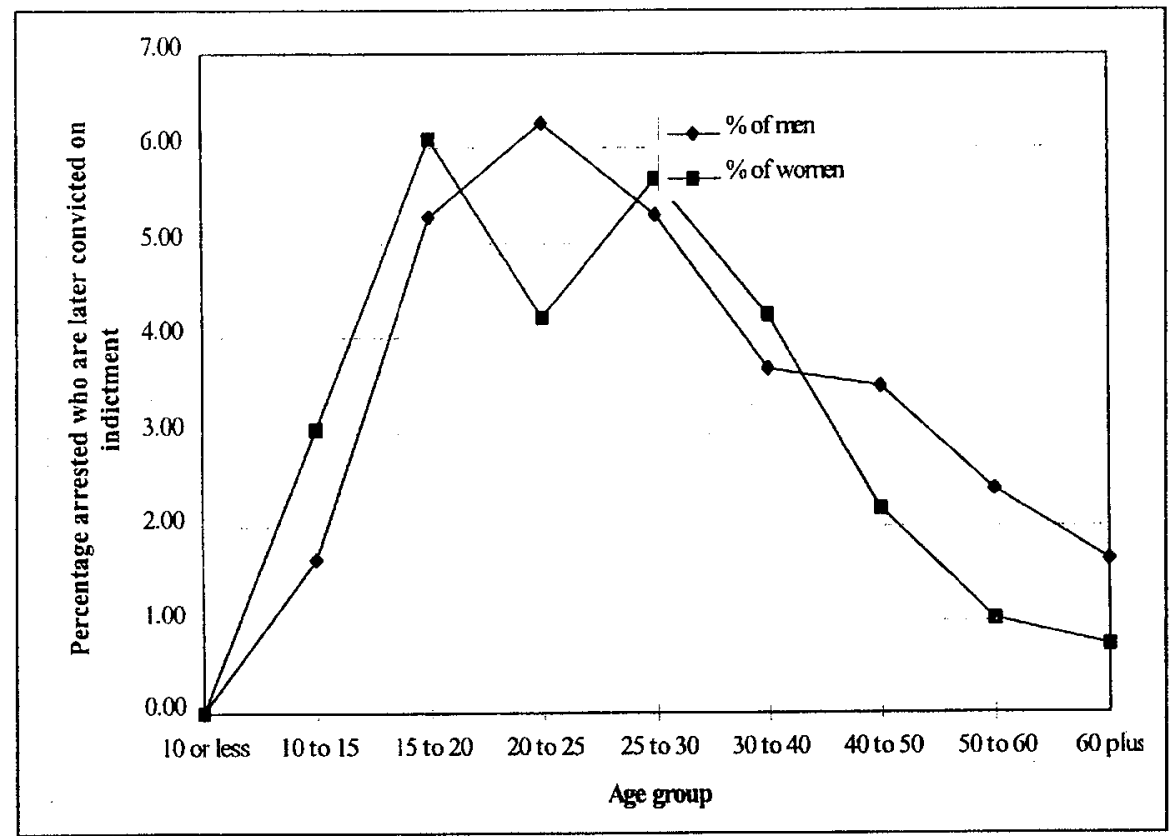

Graph Two: Differences in the chance of conviction: percentage of those arrested and those convicted on indictment, divided by age and gender.

This data on ages can also be used to establish one of the differences between those arrested and those committed for trial. The proportion of those arrested that is convicted of an indictable offence varies considerably between age groups. This is represented by Graph Two. None of the 119 persons under 10 were convicted on indictment. Only $1.8 \%$ of those aged 10 to 15 were, and while the proportion for the age-groups between 15 and 30 is relatively constant at between $5.4 \%$ and $5.9 \%$, for the 30 to 40 age-group it is $3.8 \%$, and for the 40 to 50 age group $3.3 \%$. It is only $2.2 \%$ for the 50 to 60 year-olds and $1.5 \%$ for those above 60 . The large number of women receiving summary sentences for prostitution helps to explain the gendered difference in progression rates that is most apparent for the 20 to 25 age-group. This uneven progression through the system makes an important point about the unrepresentative nature of records dealing only with indictable offences, and studies based on these records. A larger proportion of older and younger people were not making it onto these statistics. Possibly, this was because they were in fact being arrested for less serious crimes. Alternatively, the exercise of discretion by public, police and/or justices could result in their cases having a higher likelihood of resulting in summary conviction or discharge.

One cogent explanation for the low level of arrests of children can be found in a reluctance of victims to prosecute young offenders ${ }^{28}$. Another is a widespread tole-

${ }^{28}$ Leniency towards the young has been noted for the late eighteenth and early nineteenth century by King and Noel. King and Noel (1993, p. 28). 
rance of extra-judicial punishment. It was accepted that violence could be used on disorderly children in public places. In 1839 a magistrate complained that rather than bring disorderly boys before him, locals should have flogged them with a stick $^{29}$. Public violence had limits, though, and the law was harsh to those who overstepped the mark ${ }^{30}$.

The overall proportion of women in the total figure of those arrested between 1845 and 1856 is $14 \%{ }^{31}$. This rate varies from offence to offence. Unsurprisingly, the category of «disorderly prostitutes» is $100 \%$ female - this offence alone accounts for around a fifth of the 5,500 women arrested. Women represent twice this average proportion, $28 \%$ or more, in the categories of «receiving stolen goods», « larceny from the person » and «pawning or disposing of property illegally». They represent between $20 \%$ and $28 \%$ of those held for the offences of «miscellaneous vagrants », «vagrants begging », and 'felony' - the category that includes most theft. Conversely, women make up less that $8 \%$ of those arrested for all crimes of violence. Only 161 were arrested for common assault - just $4.2 \%$ of the total. So while prosecuted crime as a whole was mainly «male», those arrested for violent crime were overwhelmingly men. It must be pointed out that while only $5.5 \%$ of the 277 arrested for assault in 1859 were women, $26 \%$ of the 941 charged with assault via summons from a private individual in that year were female.

The patterns of arrest, discharge, summary conviction and acquittal do show a marked gender differentiation, as shown in Table One. Women were arrested for different crimes. Women were also treated differently after arrest. In the period 1845 1856 , the overall discharge rate for men was $25.8 \%$. For women, it was $51.8 \%$. This is consistent with Zedner's conclusions on the way that criminal women were often treated in the nineteenth century: «women were less vigorously pursued than men, that judgements made upon those who were prosecuted were less severe, and that punishments meted out were less harsh $\gg^{32}$. To an extent, this difference is accounted for by the nature of the offences with which women were charged. As prosecuted, larceny appears a very 'female' crime $-20.1 \%$ of those arrested were women. However, even within this charge, women were more likely to be discharged than men : their rate was $69.9 \%$ while that of men was $59.9 \%$. The same pattern is even more visible for alcohol-related offences. For 'drunk and incapable', $62.0 \%$ of women were discharged, but only $23.1 \%$ of men. For «drunk and disorderly», the figures were $55.0 \%$ and $17.7 \%$ respectively. For these two offences, 1,752 women were arrested : $29 \%$ of the total number of women arrested.

\section{III.}

The sheer size of the police intervention - as detailed in Table Two - is significant. In 1852 over 4,000 people were arrested - this was $3 \%$ of the borough's popu-

29 Sheffield Mercury, June 22, 1839.

30 See the case of assault on a boy by Edward Lucas, Sheffield Mercury, August 22, 1840.

31 This compares with a national total of $21.2 \%$ in 1857 , for women proceeded against for a summary offence. Zedner (1991, p. 308). These figures, however, are based on totals of those arrested and summoned. As we shall see, however, the proportion of women summoned was far higher than the proportion of women arrested.

32 Zedner (1991, p. 26). 
lation. Once we take into account the fact that the majority of those arrested were young men, the proportion who passed through the police's hands in any one year becomes even more significant. This figure does not appear to be dominated by the same people being arrested again and again. In 1859 , the returns state that only $28 \%$ of the arrests were of people «previously known to the police». If anything like that proportion was the case for the other years of mid-century, then the reach of the police as a institution over a long period of time is indeed $\left\langle\right.$ startling ${ }^{33}$. It is possible to attempt to work out how many were likely to have been arrested in total. The target figure here is the percentage of men in the town who were likely to have had experience of arrest. Gatrell sets up a bench-mark against which he compares the growth of the forces of law: he uses the modern chance that a man will be arrested during his lifetime, which is $29 \%$.

The model presented here involves adding the number of men arrested for the first time - minus a proportion who were «just passing through »- to a cumulative total. This total is reduced annually by a «wastage rate» to represent people who have died or left the town. Several assumptions were also made, all tending to make the final percentage lower. First, it is assumed that nobody had been arrested before 1844. Second, the possibility that many of the thousands of people moving to the city would have been arrested elsewhere is ignored. Third, the proportion of «strangers $\gg$ arrested each year - given in six years of the returns - is averaged at 12\%: this includes a period when the Chief Constable was anxious to blame as much crime as possible on «strangers ». The results below refer to a number of different iterations of the model, and give an impression of how altering the variables alters the «final» result.

Table Three: Modelling arrest rates.

\begin{tabular}{|c|c|c|c|c|c|c|}
\hline Initial variables & \multicolumn{2}{|c|}{ Conservative estimate } & \multicolumn{2}{|c|}{ Best fit - all males } & \multicolumn{2}{|c|}{ Best fit - adult males } \\
\hline $\begin{array}{l}\text { Wastage (yr.) } \\
\text { Sub-pop prop } \\
\text { Re-arrest prop }\end{array}$ & \multicolumn{2}{|c|}{$\begin{array}{l}0.10 \\
0.50 \\
0.50 \\
\end{array}$} & \multicolumn{2}{|c|}{$\begin{array}{r}0.05 \\
0.50 \\
0.31 \\
\end{array}$} & \multicolumn{2}{|c|}{$\begin{array}{r}0.05 \\
0.35 \\
0.31 \\
\end{array}$} \\
\hline Year & $\begin{array}{l}\text { Percentage } \\
\text { ever arrested }\end{array}$ & $\begin{array}{l}\text { Number ever } \\
\text { arrested }\end{array}$ & $\begin{array}{l}\text { Percentage } \\
\text { ever arrested }\end{array}$ & $\begin{array}{c}\text { Number } \\
\text { ever arrested }\end{array}$ & $\begin{array}{l}\text { Percentage } \\
\text { ever arrested }\end{array}$ & $\begin{array}{c}\text { Number } \\
\text { ever arrested }\end{array}$ \\
\hline 1852 & 9.22 & 6436 & 15.58 & 10873 & 22.25 & 10873 \\
\hline 1853 & 9.87 & 7110 & 17.01 & 12247 & 24.29 & 12247 \\
\hline 1854 & 10.47 & 7781 & 18.36 & 13648 & 26.23 & 13648 \\
\hline 1855 & 10.63 & 8149 & 19.08 & 14636 & 27.26 & 14636 \\
\hline 1856 & 10.69 & 8456 & 19.63 & 15538 & 28.05 & 15538 \\
\hline 1857 & 10.55 & 8617 & 19.87 & 16228 & 28.39 & 16228 \\
\hline 1858 & 10.40 & 8761 & 20.04 & 16883 & 28.62 & 16883 \\
\hline 1859 & 10.21 & 8876 & 20.11 & 17483 & 28.72 & 17483 \\
\hline 1860 & 9.77 & 8766 & 19.77 & 17741 & 28.25 & 17741 \\
\hline 1861 & 9.56 & 8851 & 19.72 & 18255 & 28.17 & 18255 \\
\hline 1862 & 9.29 & 8825 & 19.57 & 18594 & 27.95 & 18594 \\
\hline
\end{tabular}

33 Gatrell (1990, p. 279).

34 Gatrell (1990, p. 278). 
The « wastage rate» is the proportion of the town's male population who moved away or died each year: it is admittedly difficult to estimate. The «sub-pop prop » is the percentage of the overall population who were subject to significant amounts of police interference: 0.50 therefore counts all males, 0.35 counts the $70 \%$ who could be categorised as «adults». The «re-arrest prop» is the proportion of all those arrested who had ever been arrested in the past. The «best fit» columns for all males and for adult males use a repeat rate that was close to the average for the four years (1859-62) when it was included in the returns. The «conservative estimate» selects initial variables in order to arrive at a minimum likely estimate for the percentage arrested. Even for the male population as a whole, some highly conservative estimates need to be adopted to end up with a figure of less than $10 \%$ arrested by 1862 . A more likely estimate would be around $25 \%$ for adult working class men.

Davis has questioned the extent to which the nineteenth-century state «was either able or willing to intervene in the everyday affairs of its subjects through the agency of the newly organised police courts in order to systematically suppress law breaking $»^{35}$. Conversely, Gatrell sees the 1860 s as the starting point of the «policeman-state ${ }^{36}$. The conclusions that can be drawn from the work above suggest that even before the $1860 \mathrm{~s}$, the "reach" of the police across society was very wide. Sheffield was one of the most thinly-policed large towns in the country: Liverpool, Manchester, Hull and London had far more police per head of population, while, Birmingham and Leeds had substantially more ${ }^{37}$. So Sheffield cannot be considered merely an exception to a general rule. As Gatrell points out, urban areas felt the impact of the policeman-state first, and the police/population ratio for much of the rest of the country was lower than Sheffield's. The average rate for county forces in 1861 was 1:1,489, for borough forces it was 1:792, and for the Metropolitan force, $1: 504^{38}$. Sheffield's ratio in 1861 stood at $1: 969^{39}$.

\section{IV.}

Arrest data reliably records an intervention. There are indications that the nature of the intervention, and thus the 'crime' that the arrest refers to, cannot be simply lifted from the returns. The most significant decision that was taken was the initial decision as to which charge a prisoner would face. This certainly had something to do with the " reality » of what the prisoner had done, but the decision to charge could involve a retrospective labelling process, the label may have been attached to the arrest as a consequence of the magistrates' decision. In the 12-year run, $94.0 \%$ of male «suspicious characters» were discharged - after 1849 nobody is ever convicted for being one. Conversely, $97.5 \%$ of male «rogues and vagabonds» were summarily convicted - and after 1854 none is recorded as ever being discharged. It seems that the two «offences» cover a category of people were being arrested who,

\footnotetext{
5 Davis $(1984$, p. 315).

36 Gatrell (1990, p. 263).

37 Gatrell and Hadden (1972, p. 358).

38 Gatrell and Hadden (1972, p. 275).

39 WCM, Oct. $25,1860$.
} 
if released, were deemed to have been «suspicious persons» all along. If convicted, they were retrospectively tagged as «rogues and vagabonds ».

This labelling process was part of a very flexible use of the law's categories to advance the police's desired outcomes, without regard for legal categories or the law itself. One use of the «unwritten law » was the use of effective banishment by the police and the magistrates. Charges could be dropped on condition that the accused "promised to leave the town». The police also issued the tickets to vagrants in the casual ward: this gave them a considerable degree of power over the itinerant poor and the destitute ${ }^{40}$. The police used informal banishment against the marginal ${ }^{41}$. In 1837 a magistrate refrained from convicting a notorious brothel-keeper, provided that she leave Sheffield ${ }^{42}$.

The process whereby the criminal justice system re-labelled offenders continued from interaction with the police to the decision taken by the borough magistrates at Petty Sessions as to what charge the prisoner should face. This was especially significant for property crime: expensive to prosecute, but carrying a serious penalty. There were three main categories of property crime. A substantial proportion of it was, even before 1855 , prosecuted as a misdemeanour rather than a felony. This covered 775 arrests, $13 \%$ of all those arrested under Category III (that devoted to offences against property not involving violence) between 1845 and 1856. These offences were: «Robbery in Gardens, \&c»; «Obtaining Money or Goods by false pretences »; «Pawning or disposing of property illegally»; «Embezzlement»; and «Frauds». The characteristic pattern for «summary robbery» is of lower (39\%) discharge rates and higher summary conviction rates ${ }^{43}$.

The majority of property crime (4,928 arrests in 1844-1855) was prosecuted on indictment as larceny. The characteristic pattern here was of a high discharge rate, and a low committal rate. A very small proportion (205 arrests) of property crime was violent, or potentially so. This was prosecuted under the categories of: «Robbery from the person by force or threat», «Burglary», and «Assaults, with intent to commit robbery ». The average pattern for these offences involved a low (37\%) discharge rate, and a high (60\%) committal rate. Of those committed, though, only $70 \%$ were convicted: a lower rate than those for non-violent indictable property crime $(81 \%)$ and summary property crime $(87 \%)$.

Close attention to the changes in the way that the numbers were produced can cast some more light on the extent to which the statistics are distorted, and therefore help to study how that distortion changes over time. It is possible to examine the degree in which legislation, personnel, and procedural change - in the form of the 1855 Criminal Justice Act and the Juvenile Offenders Acts of 1847 - altered the statistical record. They broadened the scope of summary jurisdiction to include a number of crimes (chiefly thefts of small amounts of money) that would previously

40 'Non-wage costs of the Sheffield Police Force, 1859-1865' Sheffield City Archives, CA 295/C 2/2, lists a bill for printing 500 Billet 'Tickets, March 1859, p. 20.

41 For an example see J.C. Symons, Report on the Trades of Sheffield and on the moral and physical condition of the Young Persons employed in them made under the authority of the royal commission of enquiry into the employment of children in trades and manufactures not under the factory acts (Sheffield, Robert Leader, Independent Office, 1843), p. 8.

43 Of course, the other two categories of property crime were prosecuted only on indictment, and thus had a summary conviction rate of zero before 1855 . 
have been triable on indictment only. This was a highly significant change in the jurisdiction of Petty Sessions ${ }^{44}$. The data gathered here makes an assessment of the exact impact of the Acts possible. It clarifies one variable that stands between trends in «recorded criminals» and those in «actual crime»: many more remain.

Table Four: The impact of extending summary jurisdiction.

\begin{tabular}{|c|c|c|c|c|c|c|c|c|c|}
\hline & & Arested & $\begin{array}{c}\text { Discharged } \\
\text { by magistrates }\end{array}$ & $\begin{array}{l}\text { Convicted } \\
\text { under } \mathrm{CIA}\end{array}$ & $\begin{array}{l}\text { Convicted } \\
\text { under JOAs }\end{array}$ & Indicted & Convicted & Acquitted & $\begin{array}{l}\text { 'Bill not } \\
\text { found' } \\
\text { of not } \\
\text { prosecuted }\end{array}$ \\
\hline $\begin{array}{l}\text { Averages } \\
\mathbf{1 8 5 0 - 1 8 5 3}\end{array}$ & $\begin{array}{l}\text { Male } \\
\text { Fem. } \\
\text { Total }\end{array}$ & $\begin{array}{c}275 \\
60 \\
335\end{array}$ & $\begin{array}{c}179 \\
44 \\
223\end{array}$ & $\begin{array}{l}0 \\
0 \\
0\end{array}$ & $\begin{array}{l}\text { 0 } \\
\text { 0 } \\
\text { 0 }\end{array}$ & $\begin{array}{c}96 \\
16 \\
113\end{array}$ & $\begin{array}{l}80 \\
14 \\
94\end{array}$ & $\begin{array}{c}14 \\
2 \\
16\end{array}$ & $\begin{array}{l}2 \\
1 \\
3\end{array}$ \\
\hline (per 100,000) & Total & 243 & 162 & 0 & $\mathbf{0}$ & 82 & 68 & 12 & 2 \\
\hline $\begin{array}{l}\text { Averages } \\
1857-1860 \\
\text { (per } 100,000 \text { ) }\end{array}$ & $\begin{array}{l}\text { Male } \\
\text { Fem. } \\
\text { Total } \\
\text { Total }\end{array}$ & $\begin{array}{l}278 \\
101 \\
378 \\
221\end{array}$ & $\begin{array}{c}100 \\
44 \\
144 \\
84\end{array}$ & $\begin{array}{l}64 \\
31 \\
95 \\
55\end{array}$ & $\begin{array}{c}38 \\
9 \\
47 \\
27\end{array}$ & $\begin{array}{l}77 \\
17 \\
93 \\
54\end{array}$ & $\begin{array}{l}63 \\
13 \\
76 \\
44\end{array}$ & $\begin{array}{c}12 \\
4 \\
16 \\
9\end{array}$ & $\begin{array}{l}2 \\
0 \\
2 \\
1\end{array}$ \\
\hline & & & \multicolumn{4}{|c|}{ Percentage in custody who are: } & \multicolumn{3}{|c|}{ Percentage committed who are: } \\
\hline & & & Discharged & $\begin{array}{c}\text { Convicted } \\
\text { under CJA }\end{array}$ & $\begin{array}{c}\text { Convicted } \\
\text { under JOAs }\end{array}$ & Indicted & Convicted & Acquitted & $\begin{array}{l}\text { 'Bill not } \\
\text { found' } \\
\text { or not } \\
\text { prosecuted }\end{array}$ \\
\hline $\begin{array}{l}\text { Percentages } \\
1850-1853\end{array}$ & $\begin{array}{l}\text { Male } \\
\text { Fem. } \\
\text { Total }\end{array}$ & $\begin{array}{l}100.0 \\
100.0 \\
100.0\end{array}$ & $\begin{array}{l}65.0 \\
73.0 \\
66.4\end{array}$ & $\begin{array}{l}0.0 \\
0.0 \\
0.0\end{array}$ & $\begin{array}{l}0.0 \\
0.0 \\
0.0\end{array}$ & $\begin{array}{l}35.0 \\
27.0 \\
33.6\end{array}$ & $\begin{array}{l}82.9 \\
86.2 \\
83.3\end{array}$ & $\begin{array}{l}14.8 \\
10.8 \\
14.2\end{array}$ & $\begin{array}{l}2.3 \\
3.1 \\
2.4\end{array}$ \\
\hline $\begin{array}{l}\text { Percentages } \\
1857-1860\end{array}$ & $\begin{array}{l}\text { Male } \\
\text { Fem. } \\
\text { Total }\end{array}$ & $\begin{array}{l}100.0 \\
100.0 \\
100.0\end{array}$ & $\begin{array}{l}35.8 \\
43.8 \\
37.9\end{array}$ & $\begin{array}{l}23.1 \\
30.6 \\
25.1\end{array}$ & $\begin{array}{c}13.5 \\
9.2 \\
12.4\end{array}$ & $\begin{array}{l}27.5 \\
16.4 \\
24.6\end{array}$ & $\begin{array}{l}82.0 \\
77.3 \\
81.2\end{array}$ & $\begin{array}{l}16.0 \\
21.2 \\
16.9\end{array}$ & $\begin{array}{l}2.0 \\
1.5 \\
1.9\end{array}$ \\
\hline
\end{tabular}

This data in Table Four includes the various categories of robbery recorded between 1850 and 1860 under the category of «larceny »-to which its impact was confined. This offence covers the vast majority of indictable thefts ${ }^{45}$. The figures in bold record the annual averages for the various fates of those prosecuted for larceny over a four year period before the 1855 Criminal Justice Act. The rate of prosecution for those offences listed as «felonies» was low - around 35\%. This was espe-

44 Justice of the Peace, Vol. 17, No. 15, March 3, 1855, pp. 225-226, recommended an increase in the formalisation of Petty Sessions in recognition of 'the largeness of the powers thus conferred', and on June 16, 1855, Vol. 19 No. 35 described the Act as 'a revolution in the criminal law': p. 546.

45 The Juvenile Offenders Acts do not appear to have been used in Sheffield before 1855 . 
cially anomalous given that these offences constituted over $80 \%$ of all those cases that reached the quarter sessions/assizes stage. The bottleneck was probably the product of two factors. The first was the expense both in time and money of bringing a prosecution on indictment. Although costs were repaid to successful prosecutors, they tended not to cover the whole expense of prosecution, and there was of course no guarantee of success ${ }^{46}$. The second possible reason is that there were material constraints operating on the magistrates. These involved the number of criminals who could be held prisoner until quarter sessions, the number who could be tried during that time, and the ultimate capacity of the penal colonies and convict prisons. The figures in normal type on Table Four refer to the outcomes from a four-year period after it came into effect.

Before the Act, 275 men were arrested annually: afterwards the figure was 278 . Given the growth in the town's population, it is unquestionably a fall in real terms. For women, however, the figures are 60 and 101 respectively - so the extension in summary jurisdiction appears to have been accompanied by more women being arrested. The high discharge rate for women, $73 \%$ before the Act, as opposed to $65 \%$ for men, was reduced to $43 \%$, while that for men dropped to $36 \%$. Women seem more likely than men to be dealt with under the Criminal Justice Act, possibly because they tended to steal goods of lower value, thus being more likely to come within its provisions.

The Act led to a fall in the proportion of those arrested who were then indicted from one third to one quarter - or put in other terms a fall in the total number of convictions on indictment by around $20 \%$. The total number of convictions, though rose from 68 per 100,000 to 126 . This information is significant if we are to move towards any useful critique of long-term national trends as expressed in the national level of committals.

In conclusion, we can note that a very small proportion of those arrested were ever convicted of an indictable offence. Studying crime through indictable convictions alone is apt to lead to a distortion of several pictures: of offenders; of the nature of the crimes committed; and of the activity of the police. When their activity was counted in terms of arrests, the police appear to be concerned primarily with imposing a certain idea of acceptable behaviour on a population - with punishing people for acting unacceptably in public. Little of their time was spent on the sorts of crime that had identifiable victims. In so far as this is true, it reinforces the arguments first advanced by Storch - that the New Police were indeed «domestic missionaries», imposing a new standard of behaviour upon an unruly urban working class $^{47}$.

The level of intervention was massive. In the $1860 \mathrm{~s}$, a substantial number of people in Sheffield - almost certainly $20 \%$ of the total male population - would

46 Hay and Snyder $(1989$, p. 26). In 1849 Sheffield Town Council measured the reimbursed costs for each quarter sessions prosecution at $£ 8$, and for each Assize prosecution, £58. Borough of Sheffield Report of the Commission Appointed by the Town Council of the Borough of Sheffield, to consider the subject of Assize Prosecutions, and suggest some means for diminishing their cost. Sheffield Local Studies Library Pamphlet Collection, Vol. 51/5.

47 Storch (1976, p. 481). 
have had criminal records of some sort, and knowledge of what it was like to be deprived of liberty by the state, if only for a short time. This conclusion is all the more important given that Sheffield was among the more lightly policed of England's cities in the nineteenth century ${ }^{48}$. Consideration of the extensions in summary jurisdiction could enable us to apply some "correctives» to the study of the available statistics for indictable offences, tracing how they moved in relation to the continuing activity of police and prosecutors.

An examination of the police returns from one town does not, therefore, tell us much about the state of «crime». What it can do is give a picture of the criminal justice system of the period. In addition, it emphasises the fact that, rather than trying to concentrate on serious, «real» crime, historians would do well to look at the implications of the mass of arrests, which were dealt with overwhelmingly on a summary level, reflecting the police's pre-occupation with preserving, or even establishing a new threshold for, public order.

\author{
Chris A. Williams, Open University \\ History Department \\ Open University \\ Walton Hall \\ Milton Keynes \\ MK7 6AA \\ United Kingdom \\ chris.williams@open.ac.uk
}

\title{
REFERENCES
}

Chassaigne, P., Le crime de sang à Londres à l'époque Victorienne: essai d'interprétation des modèles de violence, Histoire, Économie et Société, 1993, 12, 4, pp. 506-524.

Davis, J,. Prosecutions and their context: the use of the criminal law in later nineteenthcentury London, in Hay, D., and Snyder, F., (Eds.), Policing and Prosecution in Britain 1750-1850, Oxford, Clarendon, 1989, pp. 397-426.

Davis, J., A poor man's system of justice : the London police courts in the second half of the nineteenth century, Historical Journal, 1984, 27, 2, pp. 309-335.

Garnham, N., How violent was eighteenth century Ireland? Irish Historical Studies, 199730 , 119 , pp. 377-392.

Gatrell, V.A.C., The decline of theft and violence in Victorian and Edwardian England, in Gatrell, V.A.C., Lenman, B., and Parker, G., (Eds.), Crime and the Law: The Social History of Crime in Early Modern Europe, London, Europa, 1980, pp. 238-337.

Gatrell, V.A.C., and Hadden, T., Criminal statistics and their interpretation, in Wrigley, E.A., (Ed.), Nineteenth Century Social History: Essays in the Use of Quantitative Methods for the Study of Social Data, Cambridge, Cambridge University Press, 1972, pp. 336-96.

Gatrell, V.A.C., Crime, authority and the policeman-state, in Thompson, F.M.L., (Ed.), The Cambridge Social History of Britain 1750-1950: Vol. 3 Social Agencies and Institutions, Cambridge, Cambridge University Press, 1990, pp. 243-310.

48 Taylor D. (1997, pp. 34-35). 
Hay, D., and Snyder, F., Using the criminal law: 1750-1850: policing, private prosecution and the state, in Hay, D., and Snyder, F., (Eds.), Policing and Prosecution in Britain, 17501850, Oxford, Clarendon, 1989, pp. 3-54.

Jones, D.J.V., Crime, Protest, Community and Police in Nineteenth-Century Britain, London, Routledge and Kegan Paul, 1982.

Jones, D.J.V., Crime in Nineteenth Century Wales, Cardiff, University of Wales Press, 1992.

King, P. , Noel, J., The origins of «the problem of juvenile delinquency »: the growth of juvenile prosecutions in London in the late eighteenth and early nineteenth centuries, Criminal Justice History, 1993, 14, pp. 17-41.

Philips, D., Crime and Authority in Victorian England: the Black Country 1835-1860, London, Croome Helm, 1977.

Sindall, R., Street Violence in the Nineteenth Century: Media Panic or Real Danger? Leicester, Leicester University Press, 1990.

Smith, D., Conflict and Compromise: Class Formation in English Society, 1830-1914, a Comparative Study of Birmingham and Sheffield, London, Routledge and Kegan Paul, 1982.

Taylor, D., The New Police in Nineteenth Century England: Crime, Conflict and Control, Manchester, Manchester University Press, 1997.

Taylor, D., Crime, Policing and Punishment in England, 1750-1914, Basingstoke, Macmillan, 1998.

Taylor, H., Rationing crime: the political economy of criminal statistics since the $1850 \mathrm{~s}$, Economic History Review, 1998a, 51, 3, pp. 569-590.

Taylor, H., The politics of the rising crime statistics of England and Wales, 1914-1960, Crime Histoire \& Sociétés, 1998b, 2, 1, pp. 5-28.

Tobias, J.J., Crime and Industrial Society in the Nineteenth Century, Harmondsworth, Penguin, 1967.

Welsh, D., The Reform of Urban Policing in Victorian England: A Study of Kingston upon Hull from 1836 to 1866, Ph.D. thesis, University of Hull, 1997.

Williams, C.A., Police and Crime in Sheffield, 1818-1874, Ph.D thesis, University of Sheffield, 1998.

Young, M., An Inside Job: Policing and Police Culture in Britain, Oxford, Clarendon, 1991.

Zedner, L., Women, Crime and Custody in Victorian England, Oxford, Clarendon, 1991. 